\title{
Medullary carcinoma of the thyroid with carcinoid-like features
}

\author{
H R Harach, U Bergholm
}

\begin{abstract}
Aims: To show that medullary carcinomas of the thyroid are morphologically indistinguishable from gut carcinoids: the value of histochemistry in their identification and differential diagnosis from metastatic carcinoid tumours to the thyroid and some follicular cell neoplasms.

Methods: 15 thyroid medullary carcinomas with features of gut carcinoids were histochemically studied for the presence of argyrophil and argentafinin granules, and calcitonin, thyroglobulin, and serotonin immunoreaction.

Results: Histological features of midgut (classic) carcinoids were observed in two tumours, foregut carcinoids in 12, and hindgut carcinoids in one. All tumours showed, to a greater or lesser extent, a calcitonin immunoreaction and argyrophilia. These markers were present only in a small area showing a classic pattern of thyroid medullary carcinoma in the hindgut carcinoid-like neoplasm. Argentaffin granules and serotonin immunostaining occurred in occasional cells from four foregut carcinoid-like tumours. Thyroglobulin was not expressed in all cases and amyloid stroma was expressed in three.

Conclusions: In some cases a diagnosis of metastatic carcinoid tumour to the thyroid can be considered only after ruling out clinically and histochemically medullary carcinoma of the thyroid. Immunolocalisation techniques are also essential for the differentiation between medullary carcinoma and thyroid follicular cell neoplasms that resemble carcinoid tumours. It is proposed that this tumour variant to be incorporated into current classifications as another histological subtype of $\mathbf{C}$ cell carcinoma.
\end{abstract}

(F Clin Pathol 1993;46:113-117)

Medullary carcinoma of the thyroid (MCT) was recognised as a true clinicopathological entity in 1959 by Hazard, Hawk, and Crile, ${ }^{1}$ and its importance as a separate type of thyroid tumour originating from the parafollicular cells was suggested by Williams in $1966 .^{2}$ Solid nests of polygonal, round, or spindle-shaped cells surrounded by fibrous tissue and amyloid deposition were originally considered to be important histological features of MCT. ${ }^{134}$ Lately, C cell tumours resembling papillary, ${ }^{5}$ follicular, ${ }^{67}$ and undifferentiated carcinomas of the thyroid ${ }^{89}$ have been recognised.

Early studies implied that MCT might resemble gut carcinoids on cytochemical, ultrastructural, and clinical grounds. ${ }^{41011}$
Morphologically, trabecular, ribbony, palisading, insular, or carcinoid patterns have been described in MCT, ${ }^{1341213}$ and a differential diagnosis from rare carcinoid tumours metastatic to the thyroid was considered. ${ }^{121415}$

We studied MCTs showing histological features indistinguishable from gut carcinoids to find out the value of immunohistochemistry in their identification and in their differential diagnosis from metastatic carcinoid tumours to the thyroid and some follicular cell neoplasms.

\section{Methods}

Fourteen of the 15 MCTs studied were found in a review of 122 thyroid C cell carcinomas available from the National Board of Health and Welfare in Sweden. Clinical data of the patients are summarised in table 1 . One of the cases was found in a review of 179 non-MCTs from the Swedish Cancer Registry. No clinical details were available in this 68 year old woman (case 15).

Representative, formalin fixed, and paraffin wax embedded tissue from each case was selected for histological and histochemical evaluation. In 13 cases the primary tumour was analysed, while in the other two cases (cases 7 and 13) only metastatic tumour in lymph nodes of the neck was available. The cases were stained with haematoxylin and eosin, Alcian blue ( $\mathrm{pH}$ 2.5)-PAS diastase method (14 cases), slightly modified Grimelius argyrophil, ${ }^{16}$ and Masson argentaffin silver techniques, ${ }^{17}$ and Congo red for amyloid. Further sections were immunostained for the demonstration of thyroglobulin, calcitonin, and serotonin (13 cases) using the biotinavidin complex method (Vectastain, Vector Labs, Inc., USA) with diaminobenzidine as chromogen. Polyclonal antisera to thyroglobulin (Dakopatts, Copenhagen, Denmark, code A251) and calcitonin (Immuno Nuclear Corporation, Stillwater, Minnesota, USA, code 207), and monoclonal antibody to serotonin (Sera-Lab, Ltd, Crawley Down, Sussex, England, code MAS 055), were used at dilutions of 1 in 15000,1 in 600, and 1 in 800, respectively. The sections were incubated overnight at room temperature. Follicles and C cells from tumour free background thyroid and normal human gastric antrum were used as positive controls. In control tests where the primary antiserum was substituted by neutral serum, immunostaining was absent. Negative immunostaining also occurred when the relevant antigen was added to the diluted antiserum for 24 hours at $4^{\circ} \mathrm{C}$ prior to incubation with the sections.

The tumours were histologically diagnosed as MCT based on the WHO system ${ }^{18}$ and then grouped histologically according to current 
Table 1 Clinical data of 14 patients with MCT

\begin{tabular}{llllll}
\hline Case No & Sex/Age & Initial complaint & Clinical type & Follow up \\
\hline 1 & F & 67 & Mass in neck & Sporadic & 13 y: hypercalcitoninaemia \\
2 & M & 52 & Mass in neck & Sporadic & 7 y: death not related to tumour \\
3 & F & 54 & Mass in neck & Sporadic & 1 y: death with disseminated tumour \\
$4^{\star}$ & M & 34 & Mass in neck & MEN 2b & 7 y: death with disseminated tumour \\
5 & M & 37 & Mass in neck & Sporadic & 26 y: alive and free of disease \\
6 & F & 63 & Mass in neck & Sporadic & 3 y: death with disseminated tumour \\
7 & F & 78 & Mass in neck & Sporadic & 2 y: alive with metastatic disease \\
8 & F & 57 & Mass in neck & Sporadic & 8 y: death with disseminated tumour \\
9 & F & 30 & Mass in neck & Sporadic & 16 y: alive and freed of disease \\
10 & F & 73 & Mass in neck & Sporadic & 2 y: death with disseminated tumour \\
11 & F & 69 & Mass in neck & Sporadic & 5 y: alive and free of disease \\
12 & F & 51 & 0:5 cm tumour found on screening & Sporadic & 16 y: hypercalcitoninaemia \\
13 & M 75 & Mass in neck & Sporadic & 12 y: alive with metastatic disease \\
14 & F & 68 & Mass in neck & Sporadic & 3 y: alive with metastic disease \\
\hline
\end{tabular}

* Mucosal neurinomas and bilateral phaeochromocytoma present.

classifications of gut carcinoids, ${ }^{19} 20$ namely, anastomosing solid islands and nests surrounded by fibrohyalinic stroma as for classic midgut carcinoids; a tendency to a trabecular pattern as for hindgut carcinoids; and a wide architectural variety such as trabecular, palisading, lobular, ribbony and glandular (tubular and rosette-like) patterns as for foregut carcinoids. The latter group also included the pattern seen in the so-called atypical carcinoid (central necrosis, cell atypia, and high mitotic rate).

\section{Results}

HISTOLOGICAL FINDINGS

MCT from cases 1 and 2 showed histological features of midgut (classic) carcinoids (table 1). The tumours were composed of round to polygonal cells showing clear or slightly eosinophilic cytoplasm with uniform nuclei, and arranged in solid islands, and anastomosing nests surrounded by fibrohyalinising septa (fig 1). Sometimes a palisading pattern occurred as well as occasional glandular lumens within solid islands (insular pattern) (fig 1).
In case 3 the tumour resembled a hindgut carcinoid both histologically and histochemically because it was largely composed of cells with abundant cytoplasm and regular nuclei forming trabeculae, as well as some tubular structures lined by tall cells and nests surrounded by delicate fibrous stroma (fig 2 ). The cells did not stain for calcitonin and argyrophil granules and no amyloid stroma was present. Only about $10 \%$ of the tumour showed typical histological and histochemical features of MCT, including amyloid and calcitonin immunostaining (fig 8).

The other 12 tumours showed a variety of patterns as seen in foregut carcinoids. They were often composed of round to oval and polygonal cells with regular nuclei arranged mainly in lobular, nesting, and trabecular structures usually surrounded by delicate fibrous stroma (fig 3-5). Ribbony and cribriform patterns predominated in two cases (fig 4), a palisading arrangement of tumour cells occurred in another two cases (figs 3 and 6) and glandular structures in four (fig 3). Some giant cells with pleomorphic nuclei were observed in one tumour. Oxyphilic cells pre-

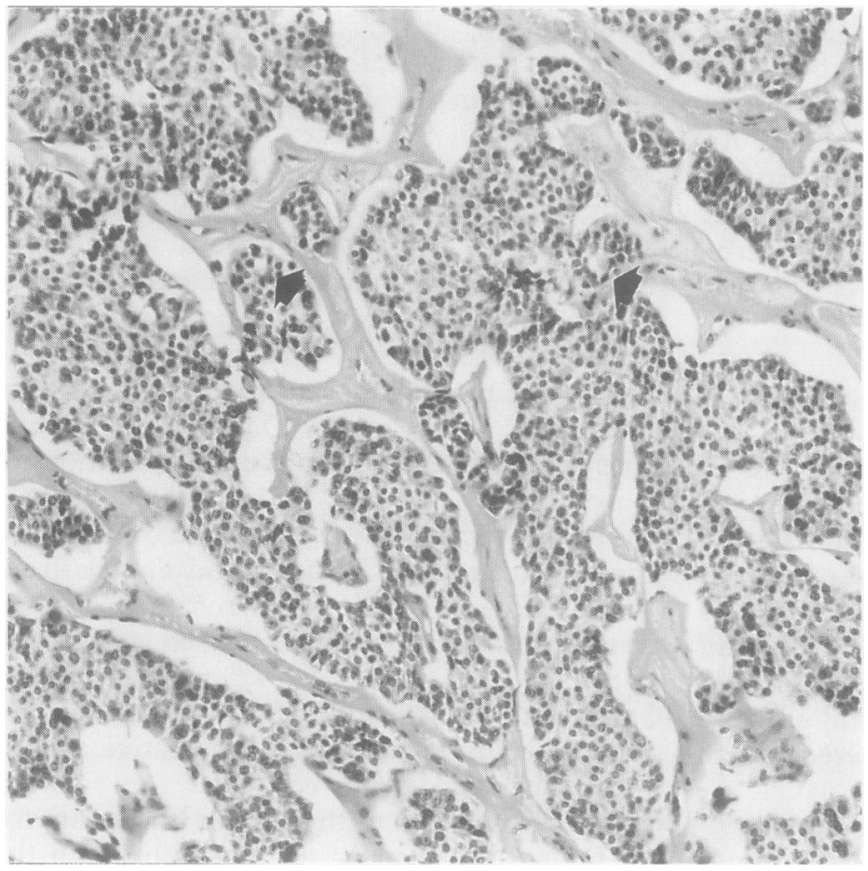

Figure 1 Case 1: solid anastomosing nests composed of round regular cells and surrounded by delicate amyloid-free hyaline stroma with thin-walled vessels. Glandular structures within solid islands are arrowed

(haematoxylin and eosin).

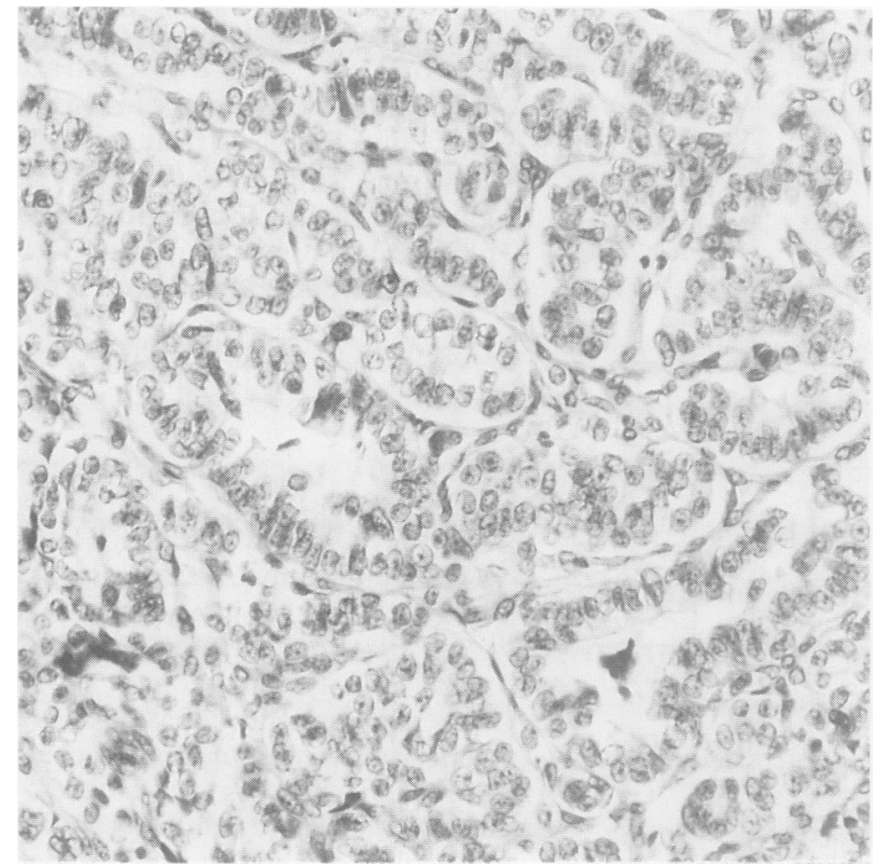

Figure 2 Case 3: trabecular and tubular structures lined by tall clear cells and surrounded by delicate fibrous stroma (haematoxylin and eosin). 
Table 2 Semiquantitative analysis of the degree of cellular staining and extent of amyloid deposits in 15 cases of MCT

\begin{tabular}{|c|c|c|c|c|c|}
\hline Case No & Amyloid & Argyrophil granules & Calcitonin & Argentaffin granules & Serotonin \\
\hline 1 & $\star \star$ & ++ & ++ & - & - \\
\hline 2 & $\star$ & +++ & +++ & - & - \\
\hline 3 & $\star$ & + & + & - & - \\
\hline 4 & $\star \star$ & ++++ & + & + & + \\
\hline 5 & $\star \star \star$ & ++++ & ++ & + & - \\
\hline 6 & $\star$ & ++++ & +++ & - & - \\
\hline 7 & - & + & +++ & - & - \\
\hline 8 & $\star \star$ & ++++ & +++ & - & - \\
\hline 9 & $\star \star$ & +++ & +++ & + & + \\
\hline 10 & - & ++++ & ++++ & - & - \\
\hline 11 & $\star \star$ & ++++ & ++++ & + & - \\
\hline 12 & $\star$ & ++ & ++++ & - & + \\
\hline 13 & $\star \star$ & ++++ & ++ & - & + \\
\hline 14 & - & ++++ & ++++ & - & - \\
\hline 15 & $\star$ & ++++ & +++ & - & - \\
\hline
\end{tabular}

$-=$ negative staining; $+=1-5 \%$ cells $++=5-25 \% ;+++=25-50 \% ;++++=>50 \%$

- = absent; ${ }^{\star}=$ isolated focus; $\star \star=$ few foci or small areas; $\star \star \star=$ large areas.

dominated in three cases; in one of them (case 10) they were arranged in solid islands with central necrosis and showed a high mitotic rate, resembling an atypical bronchial carcinoid (fig 5). Case 15 showed large pseudoglandular structures with papillary infoldings lined by multiple layers of neoplastic cells resembling pancreatic islet cell tumours (fig 7). Cases 4, 6, and 11 showed typical features of MCT in about $60 \%, 15 \%$, and $20 \%$ of the tumour area, respectively.

\section{HISTOCHEMICAL AND IMMUNOHISTOCHEMICAI}

FINDINGS

Congo red positive amyloid stroma showing green birefringence after polarisation was usually present in small amounts in 12 tumours. It was restricted to areas showing typical features of MCT in cases 3, 4, 6 and 11 from this series (table 2). Foci of calcium deposition occurred in seven tumours, in four of them it was partially related to amyloid deposits. All cases showed variable argyrophilia. Argentaffin granules and acid mucin were detected in isolated cells from four and five MCTs with features of foregut carcinoids, respectively (table 2 ).
All tumours showed a variable grade of cellular calcitonin reaction (table 2). The staining intensity was usually stronger in areas showing the typical pattern of medullary carcinoma (figs 6 and 8). A positive reaction was also observed in amyloid deposits. In case 3 calcitonin immunoreactivity and argyrophilia were negative in the areas showing a hindgut carcinoid pattern and strongly positive in the areas with typical features of MCT (fig 8). Serotonin immunoreaction was present in occasional cells from four tumours with features of foregut carcinoids, two of them showed occasional argentaffin cells as well (table 2). Thyroglobulin immunoreactivity was not observed in neoplastic cells but it was identified in normal trapped thyroid follicles at the periphery and in fibrous strands of eight tumours. In five cases the tumour cells near to normal thyroid follicles stained weakly positive for this glycoprotein.

\section{Discussion}

The differential diagnosis of MCT has been complicated in the past few years by the wide spectrum of morphological variants described

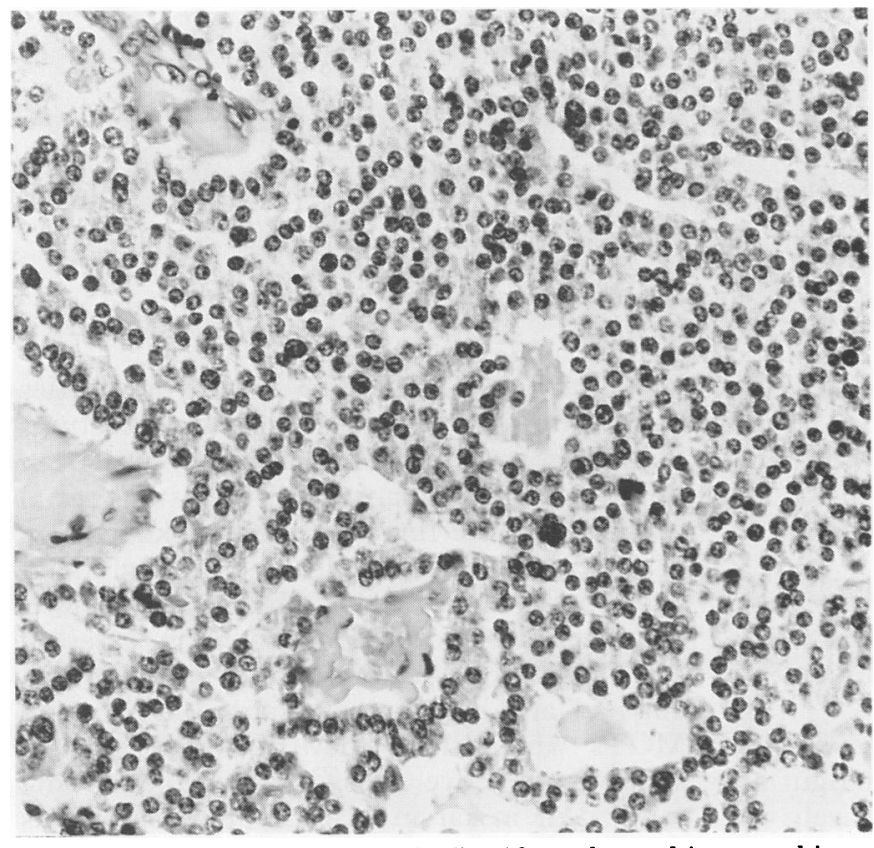

Figure 3 Case 5: neoplastic round cells with regular nuclei arranged in a solid pattern and forming few glandular structures. Note palisading of some peripheral neoplastic cells (haematoxylin and eosin).

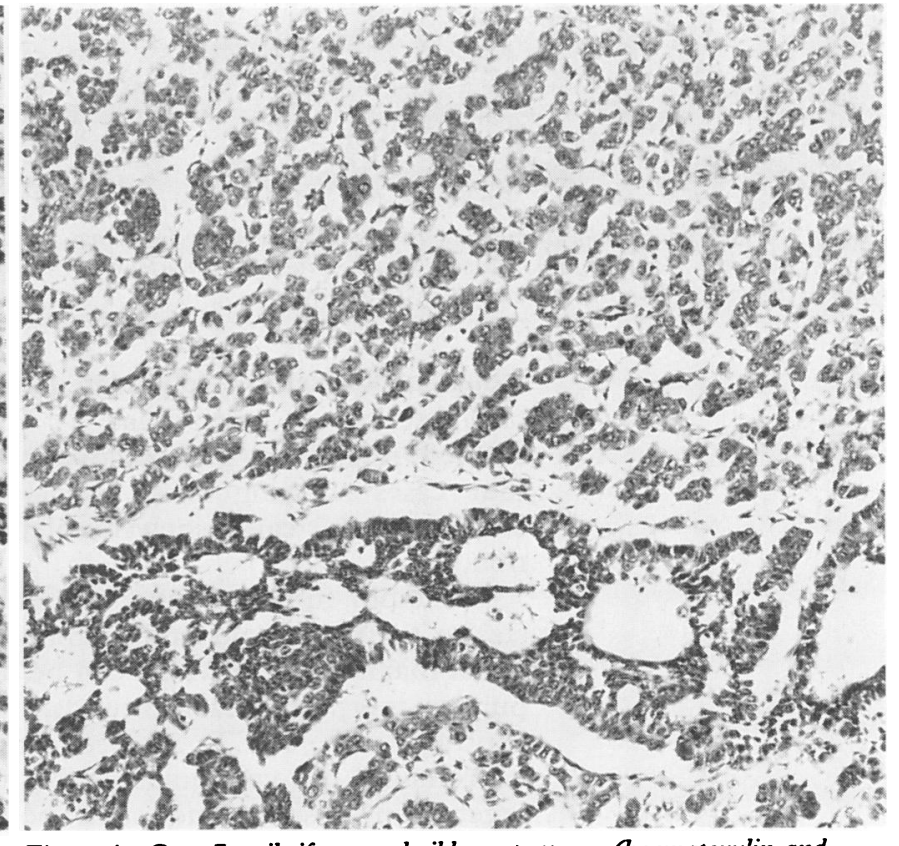

Figure 4 Case 7: cribriform and ribbony patterns (haematoxylin and eosin). 


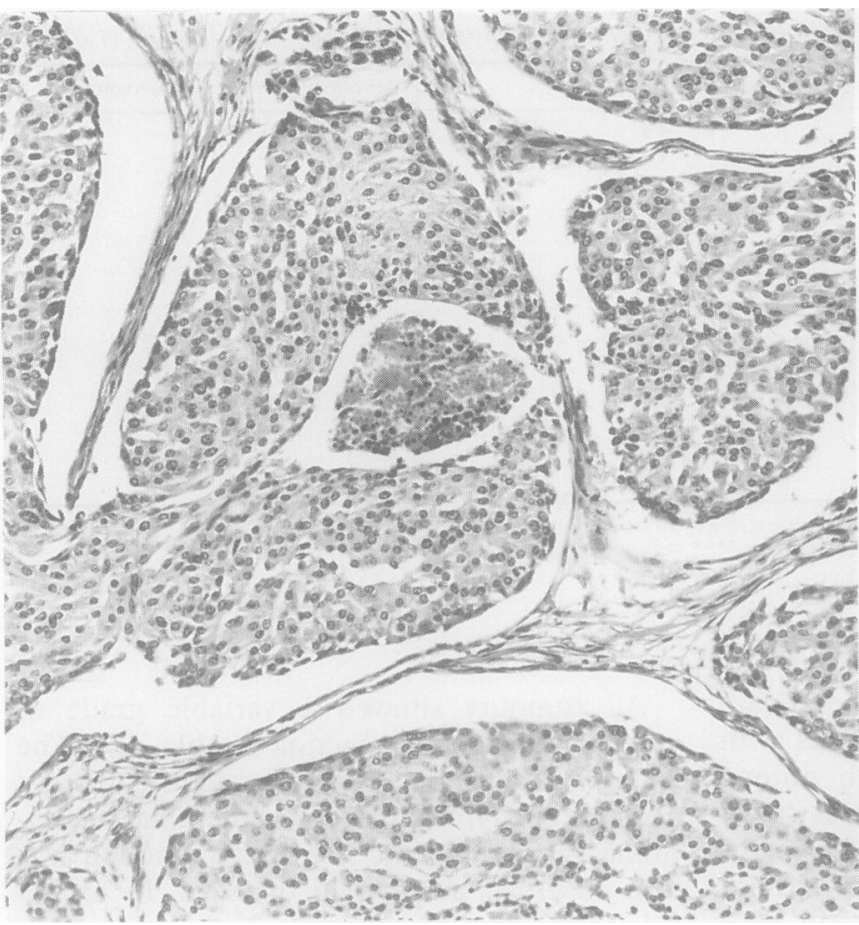

Figure 5 Case 10: solid anastomosing tumour areas of oxyphilic cells with central necrosis and surrounded by delicate fibrous stroma with thin-walled vessels (haematoxylin and eosin).

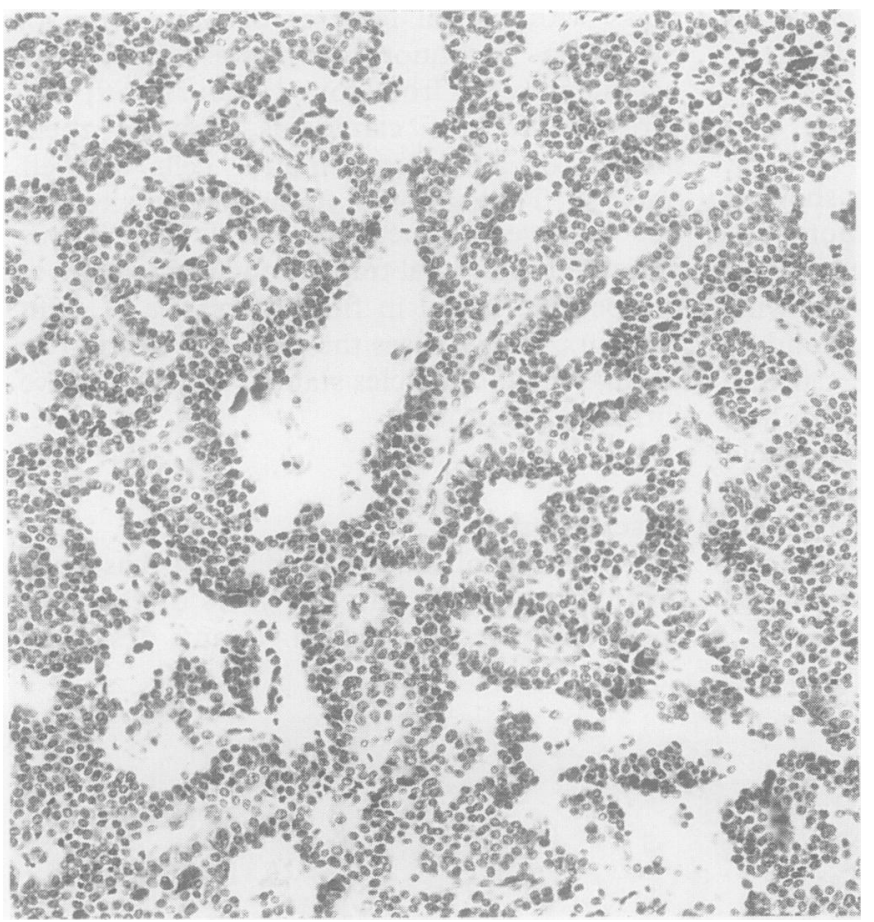

Figure 7 Case 15: pseudoglandular structures with papillary infoldings lined by multiple layers of round neoplastic cells with regular nuclei and lying in delicate stroma tissue (haematoxylin and eosin).

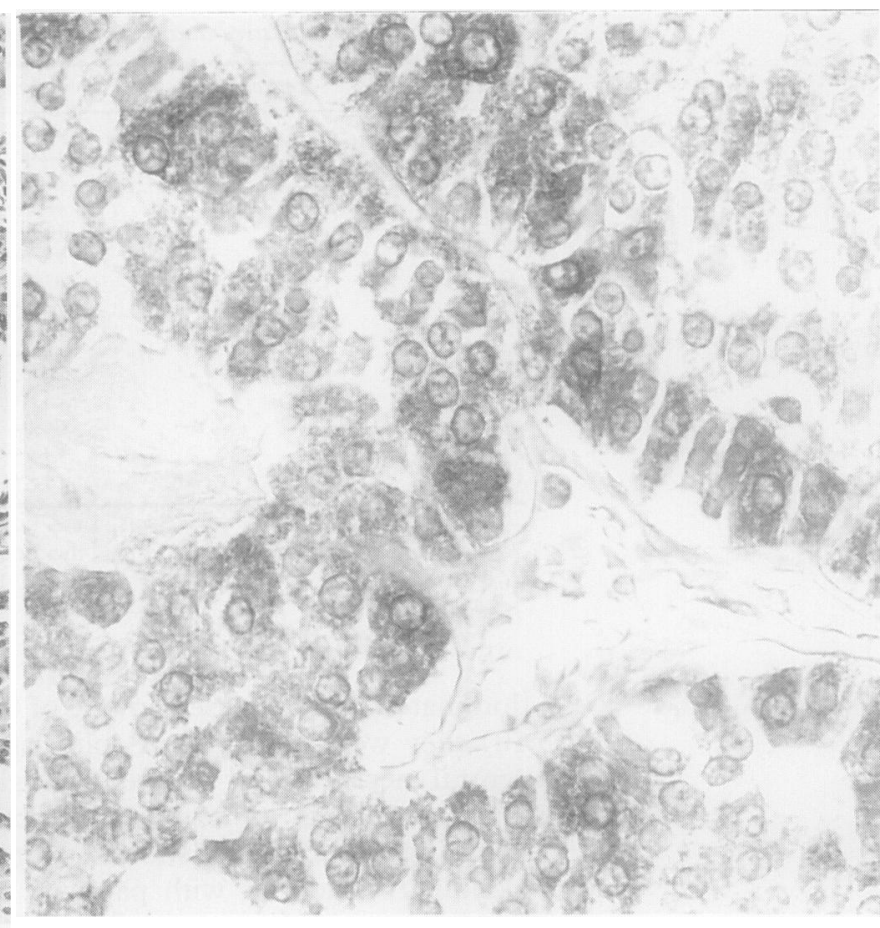

Figure 6 Case 5: tumour cells stained for calcitonin and showing palisading arrangement.

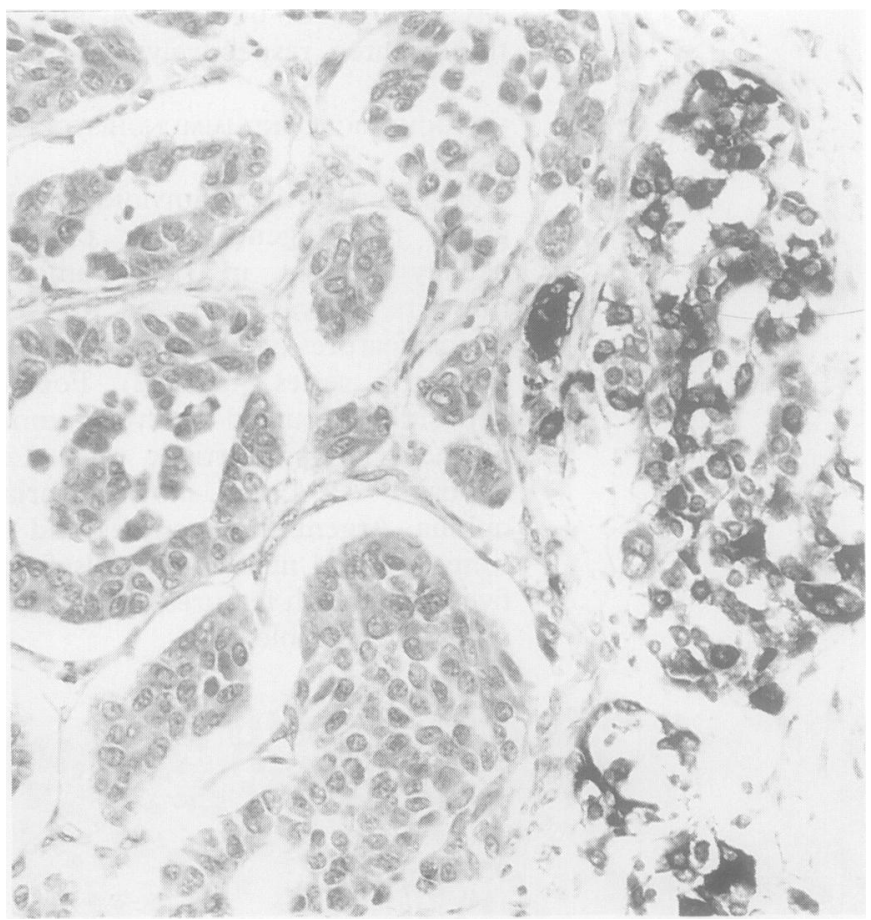

Figure 8 Case 3: strong calcitonin reaction in neoplastic cells from an area of typical medullary carcinoma (right) contrasting with adjacent negatively stained tissue with features of carcinoid tumour. which may resemble follicular, papillary, and undifferentiated carcinomas. ${ }^{5-9}$ The MCTs studied resembled gut carcinoids with only four cases showing areas typical of $\mathrm{C}$ cell carcinoma. All cases showed calcitonin reaction. ${ }^{1821}$

Carcinoid tumours can occasionally metastasise to the thyroid and histological differential diagnosis with MCT can be difficult on purely morphological grounds. ${ }^{121522}$ In contrast to the MCTs studied, classic enterochromaffin cell carcinoids of the midgut are argentaffin positive and stain positively for serotonin; hindgut carcinoids may not show argyrophilia and, together with foregut carcinoids, generally do not show calcitonin immu- nostaining. ${ }^{192324}$ Case 3 from our series showed histological and histochemical features of hindgut carcinoids. This case may have been difficult to differentiate from a metastatic rectal carcinoid to the thyroid ${ }^{15}$ without knowledge of clinical data if the small area of typical MCT had not been present. Differential diagnosis may be even more complicated in cases of MCT that are not argyrophilic and show no amyloid and calcitonin reaction, and in rare MCTs where there may be large areas of serotonin reactive cells. ${ }^{25} 26$ Amyloid stroma may occur in carcinoid tumours, ${ }^{27}$ as well as calcitonin reactive cells, but usually to a much lesser extent than in MCT. ${ }^{2328}$ Additional analysis of clinical data, investigation of further 
sections of the tumours, and the more sophisticated in situ hybridisation techniques may help to elucidate the diagnosis in such difficult cases.

The tumours studied here displayed a variety of additional morphological features, such as glandular and papillary structures, large cells and oxyphilic cells. These can be expected to occur even as a dominant pattern in medullary carcinomas. ${ }^{5-8}$ Three cases were amyloid free. ${ }^{1821}$ Differential diagnosis should be considered with follicular adenomas, especially the hyalinising trabecular variant, moderately and poorly differentiated follicular carcinomas, papillary carcinoma, and the mixed medullary-follicular carcinoma of the thyroid. All these neoplasms show, among other features, thyroglobulin reaction in neoplastic cells unlike MCT. ${ }^{29-33}$ Neoplastic cells with acid mucin were also present in five cases. Mucin production has been documented in $M_{C T}{ }^{321}$ and their histogenesis has been linked to thyroid mucinous $\mathrm{C}$ cells. ${ }^{34}$

Eight cases showed thyroglobulin reactive normal thyroid follicles at the periphery and in fibrous stands of the tumours. In five this glycoprotein also gave a weakly positive reaction in some neoplastic cells adjacent to normal thyroid follicles. These findings should be carefully interpreted to avoid a misdiagnosis of mixed medullary-follicular tumours of the thyroid. ${ }^{3031}$ Several mixed carcinomas have been reported in some series, mainly based on the identification of thyroglobulin reactivity in neoplastic cells from the central part of the tumours, ${ }^{25}$ as well as in metastases. ${ }^{30}$ The alternative explanation for thyroglobulin reaction in neoplastic cells is phagocytosis by neoplastic cells near to disrupted normal intratumoural follicles. ${ }^{721}$ The latter contention is, in our opinion, relevant to the tumours studied here.

In MCTs with carcinoid features the diagnosis can be suspected on routine microscopy, especially when there are areas with typical histological and histochemical patterns of $\mathrm{C}$ cell neoplasia. However, it might not always be an easy diagnosis, particularly when carcinoid tumours metastatic to the thyroid may occur as well as primary thyroid follicular and mixed medullary-follicular neoplasia showing similar morphological features.

These 15 cases of MCT are reported because we believe that this pattern may be mistakenly considered to be of follicular cell origin or metastatic, leading to inappropriate treatment and failure to obtain a careful family history. These cases also illustrate the great value of histochemical methods in establishing what might otherwise be a difficult diagnosis. We propose that this tumour variant should be incorporated into accepted histological subtypes of MCT. ${ }^{1821}$

We thank Professors Sir E Dillwyn Williams and Geraint T Williams for helpful comments. Professor Lars Grimelius kindly provided the material studied. This work has been supported by provided the material studied. This work has been supported by the Swedi).
6817).

1 Hazard JB, Hawk WA, Crile G jr. Medullary (solid) carcinoma of the thyroid-a clinicopatholigic entity. $f$ carcinoma of the thyroid-a clinicopath
Clin Endocrinol Metab 1959;19:152-61.

2 Williams ED. Histogenesis of medullary carcinoma of the thyroid. F Clin Pathol 1966;19:114-8

3 Williams ED, Brown CL Doniach I. Pathological and clinical findings in a series of 67 cases of medullary carcinoma of the thyroid. $f$ Clin Pathol 1966;19:103-13.

4 Ljungberg $O$. On medullary carcinoma of the thyroid. Acta Pathol Microbiol Scand A 1972;80 (Suppl 231):1-57.

5 Kakudo K, Miyauchi A, Takai S, Katayama S, Kuma K, Kitamura H. C cell carcinoma of the thyroid - papillary type. Acta Pathol fpn 1979;29:653-9.

6 Harach HR, Williams ED. Glandular (tubular and follicular) variants of medullary carcinoma of the thyroid. Histopathology 1983;7:83-97.

7 Harach HR, Bergholm U. Medullary (C cell) carcinoma of the thyroid with features of follicular oxyphilic cell tumours. Histopathology 1988;13:645-56.

8 Kakudo K, Miyauchi A, Ogihara T, Takai SI, Kitamura M, Kosaki G, Kumahara Y. Medullary carcinoma of the thyroid: giant cell type. Arch Pathol Lab Med 1978; 102:445-7.

9 Mendelsohn G, Bigner SH, Eggleston JC, Baylin SB, Wells SA. Anaplastic variants of medullary thyroid carcinoma. A light microscopic and immunohistochemical study. $\mathrm{Am}$ f Surg Pathol 1980;4:333-41.

10 Gonzalez Licea A, Hartmann WH, Yardley JH. Medullary carcinoma of the thyroid: Ultrastructural evidence of its origin from the parafollicular cells and its possible relation to carcinoid tumors. Am $\mathcal{f}$ Clin Pathol 1968;49:512-20.

11 to carcinoid tumors. Am Foertel CG, Beahrs OH, Woolner LB, Tyce GM. "Malignant carcinoid syndrome" associated with noncarcinoid nant carcinoid syndrome" associated with

12 Dunn EL, Nishiyama RH, Thompson NW. Medullary carcinoma of the thyroid gland. Surgery 1973;73: 848-58.

13 Saad MF, Ordonez NG, Rashid RK, Guido J, Stratton Hill C jr, Hickey RC, Samaan NA. Medullary carcinoma of the thyroid: A study of the clinical features and prognostic factors in 161 patients. Medicine 1984;63: 319-42.

14 Nesland JM, Sobrinho-Simoes M, Holm R, Johannessen JV. Organoid tumor in the thyroid gland. Ultrastruct Pathol 1985;9:65-70.

15 Lertprasertsuke N, Kakudo K, Satoh S, Tada N, Osamura Y. Rectal carcinoid tumor metastasising to the thyroid and pancreas. An autopsy case exploiting immunohistochemistry for differentiation from tumors involving multiple endocrine organs. Acta Pathol fpn 1990;40:352-60.

16 Grimelius L, Wilander E. Silver stains in the study of endocrine cells of the gut and pancreas. Invest Cell Pathol 1980;3:3-12.

17 Portela Gomez GM, Grimelius L. Identification and characterisation of enterochromaffin cells with different staining techniques. Acta Histochem 1986;79:161-74.

18 Hedinger C, Williams ED, Sobin LH. Histological typing of thyroid tumours. In: International histological classificaof thyroid tumours. In: International histological classifica

19 Williams ED, Sandler M. The classification of carcinoid tumours. Lancet 1963;i:238-9.

20 Williams ED, Siebenmann RE, Sobin LH. Histological typing of endocrine tumours. In: International histological classification of tumours. No 23. Geneva: WHO, 1980: $46-52$.

21 Albores-Saavedra J, Li Volsi VA, Williams ED. Medullary carcinoma. Semin Diagnost Pathol 1985;2:137-46.

22 Berge T, Linell F. Carcinoid tumours: Frequency in a defined population during a 12 year period. Acta Pathol Microbiol Scand A 1976;84:322-30.

23 Dayal Y, Lin HD, Tallberg K, Reichlin S, DeLellis RA, Wolfe HJ. Immunocytochemical demonstration of growth hormone-releasing factor in gastrointestinal and panhormone-releasing factor in gastrointestinal and pan85:13-20.

24 Federspiel BH, Burke AP, Sobin LH, Shekitka KM. Rectal and colonic carcinoids. A clinicopathologic study of 84 cases. Cancer 1990;65:135-40.

25 Uribe M, Fenoglio-Preiser CM, Grimes M, Feind C. Medullary carcinoma of the thyroid gland: Clinical, pathological, and immunohistochemical features with review of the literature. Am $\mathcal{f}$ Surg Pathol 1985;9: 577-94.

26 Harach HR, Wilander E, Grimelius L, Bergholm U, Westermark P, Falkmer S. Chromagranin A immunoreactivity compared with argyrophilia, calcitonin immueactivity compared with argyrophilia, calcitonin immunoreactivity, and amyloid as tumour markers in the histopathological diagnosis of medullary (C-cell)

27 Al-Kaisi N, Abdul-Karim FW, Mendelsohn G, Jacobs G. Bronchial carcinoid tumor with amyloid stroma. Arch Pathol Lab Med 1988;112:211-4.

28 Harach HR, Skinner M, Gibbs AR. Biological markers in human lung carcinoma: an immunopathological study of six antigens. Thorax 1983;38:937-41.

29 Carcangiu ML, Zampi G, Rosai J. Poorly differentiated (insular") thyroid carcinoma: A reinterpretation of Langhans" "wuchernde Struma". Am f Surg Pathol 1984;8:655-68.

30 Hales M, Rosenau W, Okerlund MD, Galante M. Carcinoma of the thyroid with a mixed medullary and follicular pattern. Cancer 1982;50:1352-9.

31 Ljungberg O, Bondeson L, Bondeson AG. Differentiated thyroid carcinoma, intermediate type: a new tumor entity thyroid carcinoma, intermediate type: a new tumor entity carcinoma. Hum Pathol 1984;15:218-28.

32 Carney JA, Ryan J, Goellner JR. Hyalinizing trabecular adenoma of the thyroid gland. Am $\mathcal{f}$ Surg Pathol 1987; adenoma of

33 Harach HR. Thyroid follicles with acid mucins in man: a second kind of follicles? Cell Tissue Res 1985;242:211-5.

34 Harach HR, Franssila KO. Thyroglobulin immunostaining in follicular thyroid carcinoma: relationship to their degree of differentiation and cell type. Histopathology 1988;13:43-54. 